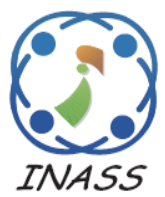

\title{
Mining Zone Determination of Natural Sandy Gravel using Fuzzy AHP and SAW, MOORA and COPRAS Methods
}

\author{
Adiba Sabilla Ajrina ${ }^{1}$ \\ Riyanarto Sarno ${ }^{2 *}$ \\ Hari Ginardi ${ }^{1}$ \\ Aziz Fajar ${ }^{2}$ \\ ${ }^{1}$ Department of Information Technology Management, Institut Teknologi Sepuluh Nopember, Surabaya, Indonesia \\ ${ }^{2}$ Department of Informatics, Institut Teknologi Sepuluh Nopember, Surabaya, Indonesia \\ * Corresponding author's Email: riyanarto@if.its.ac.id
}

\begin{abstract}
Indonesia is one country that is rich in natural resources, both natural, marine and air resources. The existence of abundant resources is not properly utilized by the people of Indonesia. Improper use of resources will cause environmental damage. One form of environmental destruction is natural Sandy Gravel (Sirtu) mining activities in Kediri Regency. This study aims to map potential place for mining areas assessed using Geographic information system (GIS) and Multi criteria choice Making (MCDM) using Simple Additive Weighting Method (SAW), Multi Objective Optimization on the basis of Ratio Analysis Method (MOORA) and Complex Proportional Assessment Method (COPRAS). The weighting of the criteria used in this study is based on the Fuzzy Analytical Hierarchy Process (F-AHP) method. GIS is used to score the criteria and build the decision matrix needed by the MCDM method. The criteria used in this study are based on UU Republik Indonesia 4/2009. Those criteria are grouped into 3 categories which are natural factors, environmental factors, and aesthetic factors. Natural Factors have sub-criteria such as geomorphology, lithology, and hydrology. Environmental factors are comprised of vegetation, wildlife, distance from main road, distance from settlements, and population density. While aesthetic factors consist of natural features and touristic places. The results showed that from the three methods used which are SAW, MOORA and COPRAS methods, the most suitable method was the COPRAS method with 19/19 aggregation values. The order of sub-districts in Kediri Regency with the most suitable potential for Natural Sandy Gravel (Sirtu) is as follows: Kras, Bulan, Papar, Tarokan, Purwoasri, Mojo, Pare, Ngadiluwih, Kukung, Kandatel, Gampengrejo, Semen, Grogol, Plosoklaten, Ngancar, Puncu, Wates, Kepung, Kandangan.
\end{abstract}

Keywords: MCDM, Fuzzy AHP, GIS, COPRAS, MOORA, SAW, Mining zone.

\section{Introduction}

Indonesia is a country comprised of many islands which contains enormous natural resources. Some of those natural resources can be gathered by mining activities. Some regions in Indonesia are famous for natural resources produced from mining activities. Those natural resources Is then can be utilized for various things to improve our lives. Unfortunately, Natural Resources such as natural sandy gravel is limited so that their use needs some considerations. Natural sandy gravel (Sirtu) in Gunung Kelud are a product of active volcanic activity. Thus, places in the Kediri Regency are ideal for the mining location of these resources. There are numerous mining activities which reduce the potential held of natural sandy gravel after mining activities. Thus, mining in the same location for a long time would reduce the profit yield from the natural resource. Hence, determine the zone which the mining activities should be held is important.

To determine the location for natural sandy gravel mining, there are several factors that needs considerations. Those factors are natural factors, environmental factors, and aesthetic factors. Since there are multiple factors that is needed for considerations, Multi Criteria Decision Making (MCDM) method can be utilized. MCDM method is used to determine the best suited alternatives based on given criteria [1]. Thus, the location of the mining activities will be the best suited to the criteria. 
The MCDM method that we utilize in this study are Simple Additive Weighting (SAW), Multi Objective Optimization on the Basis of Ratio Analysis (MOORA), and Complex Proportional Assessment (COPRAS). SAW have been used in several studies ranging from singer selection based on vowel intonation and several other criteria [2], and second-hand motorcycle [3]. MOORA have also been used in decision making system for building location [4], [5], and some production decision making process [6-8]. While, COPRAS has also performed good in several studies such as Building refurbishment decision support[9], Selection of lowe windows [10], optimizing blind spot of heavy vehicles [11], and material selection problem [12]. Using the mentioned methods, this study tries to determine the most suitable location for mining natural sandy gravel.

The main contribution of this paper is the MCDM method that is most suitable for this case with Fuzzy Analytic Hierarchy Process (AHP) to determine the weight of each criteria. By utilizing fuzzy AHP as a criterion weighting method, the result can reflect the actual importance of each criterion compared to the previous research where the weight of each criterion was not known [1]. This research is comprised of as follows: section 2 which explains the related theory to support this research, section 3 shows the proposed method, section 4 describes the results and analysis of the experiment, and section 5 concludes the research.

\section{Related theory}

Multi Criteria Decision Making (MCDM) method have been used to solve which alternative that should be used based on 2 or more criteria. MCDM have been employed in various research with various problems such as Multi-objective problem considering user preference [13], selecting Serbian banks [14], machine tool selection [15], supplier of healthcare selection [16], port choice [17], selection of clustering methods [18].

Simple Additive Weighting (SAW) have been implemented to select singers based on some criteria [2]. In the study, using SAW and Analytic Hierarchy Process (AHP) shows that compared to expert judgements, the result of the MCDM method achieve $84.61 \%$ accuracy. Another research using SAW shows a promising result in selecting a second-hand motorcycle based on some criteria [3]. Thus, shows the capability of SAW method in multi criteria decision making process.

Multi Objective Optimization on the Basis of Ratio Analysis (MOORA) have been implemented in several studies. MOORA shows a great result on its accuracy compared to several other MCDM method [1]. Other research using MOORA as the MCDM method shows that MOORA can handle MCDM problem on many case studies. MOORA have been used for selecting the best cutting parameters in milling process [7]. Other research on warehouse location selection shows that even if MOORA is more simple the performance of MOORA is similar to Technique for Order Preference by Similarity to Ideal Solution (TOPSIS) [5]. On welding process, MOORA have been successfully determine the optimal welding parameter such as the voltage, electricity current, electrode diameter, and welding speed for the best welding result [8].

Complex Proportional Assessment (COPRAS) have been favoured along with TOPSIS for material selection [12]. Based on the research, COPRAS is a simple MCDM method that can be implemented for real problem. Other research using COPRAS as an MCDM method to select low-e windows in a building retrofit [10]. COPRAS shows its capabilities to select windows and cut the window replacement costs.

AHP have been employed in various research for different purposes. AHP have been used to determine which criteria gives more contribution in a case compared to other criteria [19]. Fuzzy AHP as a method to determine the weight of criteria for MCDM method have been done in the past[20]. Based on the research, Fuzzy AHP have been successfully utilized to determine the weight of the criteria for optimization of solar farm site in Bali, Indonesia.

To select the best MCDM method, other research uses aggregation to show which method is the most suitable for the given case. A research uses the method sensitivity to criteria weight [21], while other research uses both sensitivity and accuracy[1]. However, the previously mentioned research tests the effect of weight change to the methods result. This research aims to simplify the process using method that is used to determine the suitable weight for each criterion.

\section{Research method}

This study combines the Fuzzy AHP process for weighting criteria and the spatial data analysis process using ArcMap 10.2.2. The ranking order of each alternative is determine using the SAW, MOORA and COPRAS methods. The results of the three ranking sequences are then compared.

Fig. 1 shows the whole proposed method of this study. First, we create a questionnaire to share to the experts which determine each criteria weight. Fuzzy 


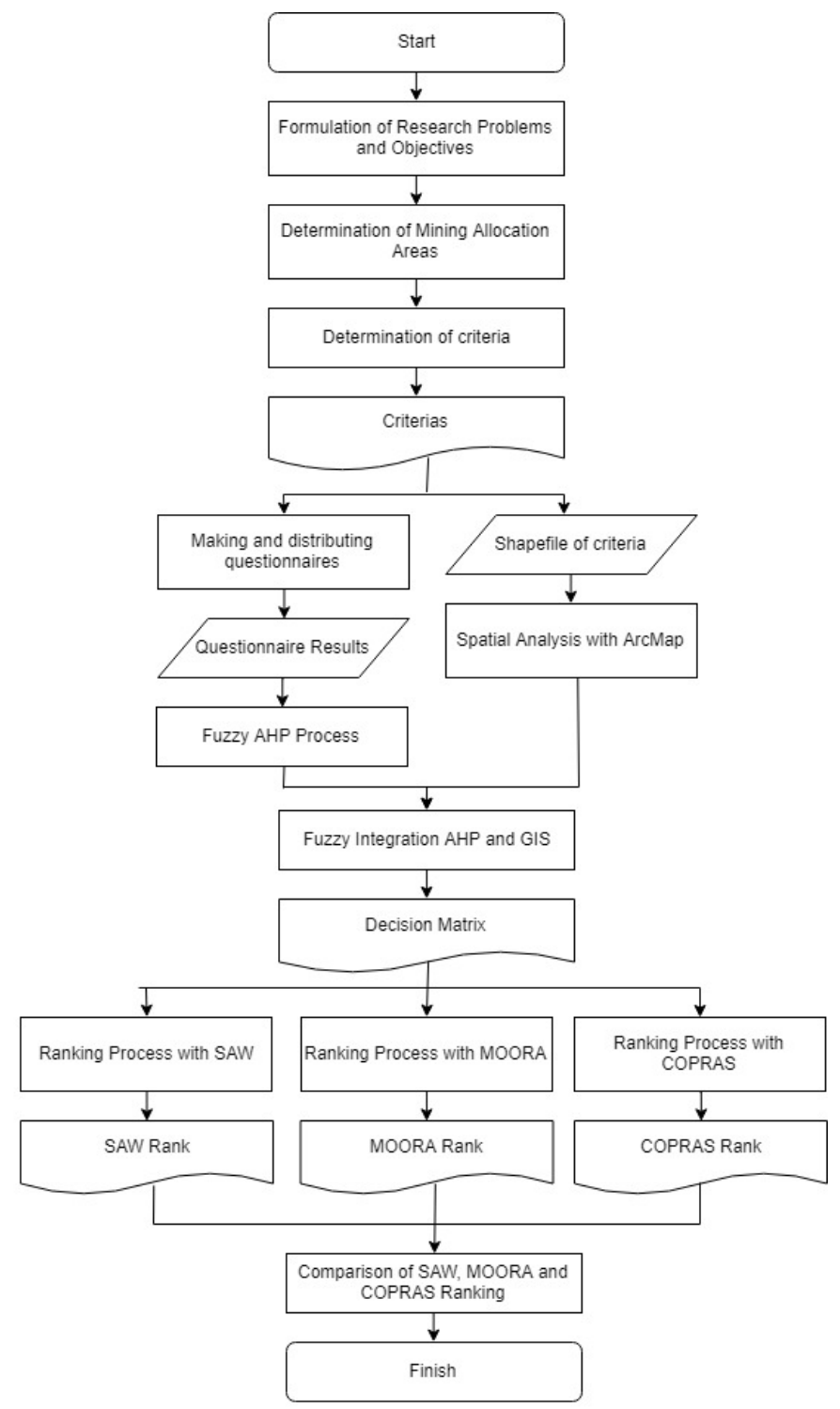

Figure 1. Research methodology

AHP is then employed to generalize the weight that is needed for MCDM method later. Since we already got the weight for each criterion, MCDM methods are then employed and produce rank of its own. The results of the MCDM methods are then compared using the accuracy based on recent studies[1].

\subsection{Determination of mining areas}

Determination of Mining Allocation Areas is based on local regulations governing Spatial and Regional Plans in Kediri District and Kediri City. There are 2 Regional Planning and Spatial Planning Regulations in Kabupaten Kediri, namely:

1. Peraturan Bupati Kediri No. 50 Year 2015 about mining allocation areas in Kediri Regency)

2. Peraturan Bupati Kediri No. 57 Year 2015 about allotment areas for Minerals and Non-Metallic Rocks in Kediri Regency.

International Journal of Intelligent Engineering and Systems, Vol.13, No.5, 2020
While the Regional Plan and Spatial Planning in the City of Kediri is Peraturan Daerah Kota Kediri Number 1 Year 2012 about spatial planning of the City of Kediri in $2011-2030$, based on these three basic regulations, the regions that are not intended for the mining area is not included in this study.

\subsection{Determination of criteria}

Determination of criteria is done by the Delphi Method, but the basis for determining the proposed criteria is the development of the definition contained in Law No. 4 year 2009 concerning Mineral and Coal Mining.

The Delphi method in this study was conducted in several rounds. In the first round, the questionnaire was distributed to respondents which are the expert of the field of work. From this round, the expected 
criteria were obtained. Then, the identified criteria were reassessed by respondents in the second round and the agreed criteria is then retrieved. These criteria were included in the third round and the following rounds until all respondents agreed to all the criteria.

\subsection{Fuzzy AHP process}

Fuzzy AHP (FAHP) is a ranking method. FAHP is a combination of AHP method and fuzzy concept approach. F-AHP covers the weaknesses found in the AHP, namely the problem with criteria that have more subjective traits. The uncertainty of numbers is represented by a sequence of scales [22]. Fuzzy AHP utilizes Triangular Fuzzy Number (TFN) to determine the degree of membership of each criterion. So, the number at the level of intensity of interest in the AHP is transformed into the TFN scale. Chang (1996) defines the value of AHP intensity into a fuzzy triangle scale which divides each fuzzy set by 2 , except for intensity of interest 1 [22].

In this study, the Fuzzy AHP method was used as an attempt to answer the sequence of potential zones of Sirtu mining in Kediri Regency including the weight of every criteria.

\subsection{Spatial analysis with arcmap}

In this study the data in the form of maps are converted into digital format and are combined to produce a map overlaying the order of importance of a criterion. Based on the consideration of the analysis a decision system matrix was produced on all criteria and each alternative sub-district.

\subsection{SAW, MOORA and COPRAS ranking process}

\subsubsection{Simple additive weighting (SAW)}

The SAW method requires the procedure of normalizing the decision matrix to a scale that can be compared with all available opportunity scores. This SAW technique also requires decision makers to decide the weight for every characteristic. The overall score for options is received through summing all of the multiplication results among the ratings and the weight of each attribute.

\subsection{Multi-objective optimization by ratio analysis (MOORA)}

MOORA method categorize the criteria of an MCDM problem into criteria that would need to be maximized or minimized. Then, includes the weight of each criterion. This method can determine the objectives of the opposing criteria. Thus, it can give rank to each of the criteria based on the categories.

\subsubsection{Complex proportional assessment (COPRAS)}

COPRAS is one of the Multi Attribute Decision Making methods (MADM) for decision making in various fields of science. The COPRAS method uses stepwise sorting and evaluates the procedures of alternatives in terms of significance and utility degrees [21].

\subsubsection{Comparison of SAW, MOORA and COPRAS ranking}

After the ranking of each sub-district with those 3 methods, then we can compare each method and get the most suitable sub-district for mining activities. The choice of the most suitable method is done by first determining the aggregate value based on the SAW, MOORA and COPRAS methods. The order of each method is then compared to the collective aggregate sequence. Thus, methods with the highest score is the most suitable method.

\section{Result and discussion}

In this sub-chapter, we discuss the classification testing on each data that has been obtained from electronic nose and evaluation of results

\subsection{Determination of criteria}

The Delphi method is done by using a questionnaire that is filled separately between participants. Opinion screening will be stopped after the answers from participants lead to convergent answers. The Delphi method in this study was conducted in 3 rounds. Then, based on the questionnaire, we assign Triangular Fuzzy Number (TFN) and Reciprocal value for each criterion. Table 1 shows the Reciprocal value of the criteria based on Delphi method.

Based on Table 1, the criteria that will be used in this study is comprised of 10 criteria and 3 groups of criteria. The first group is Natural Factors that holds the criteria which is naturally occur on the location such as geomorphology, lithology, hydrology. The second group of criteria contains Environmental Factors such as the vegetation, wildlife, distance of the location to the main road, distance of the location to the nearest settlement, and population density of the given location. The last group weights the location aesthetic if it is used as the mining location with criteria such as natural features and touristic places that will be affected. 
Table 1. Questionnaire results and fuzzy calculations

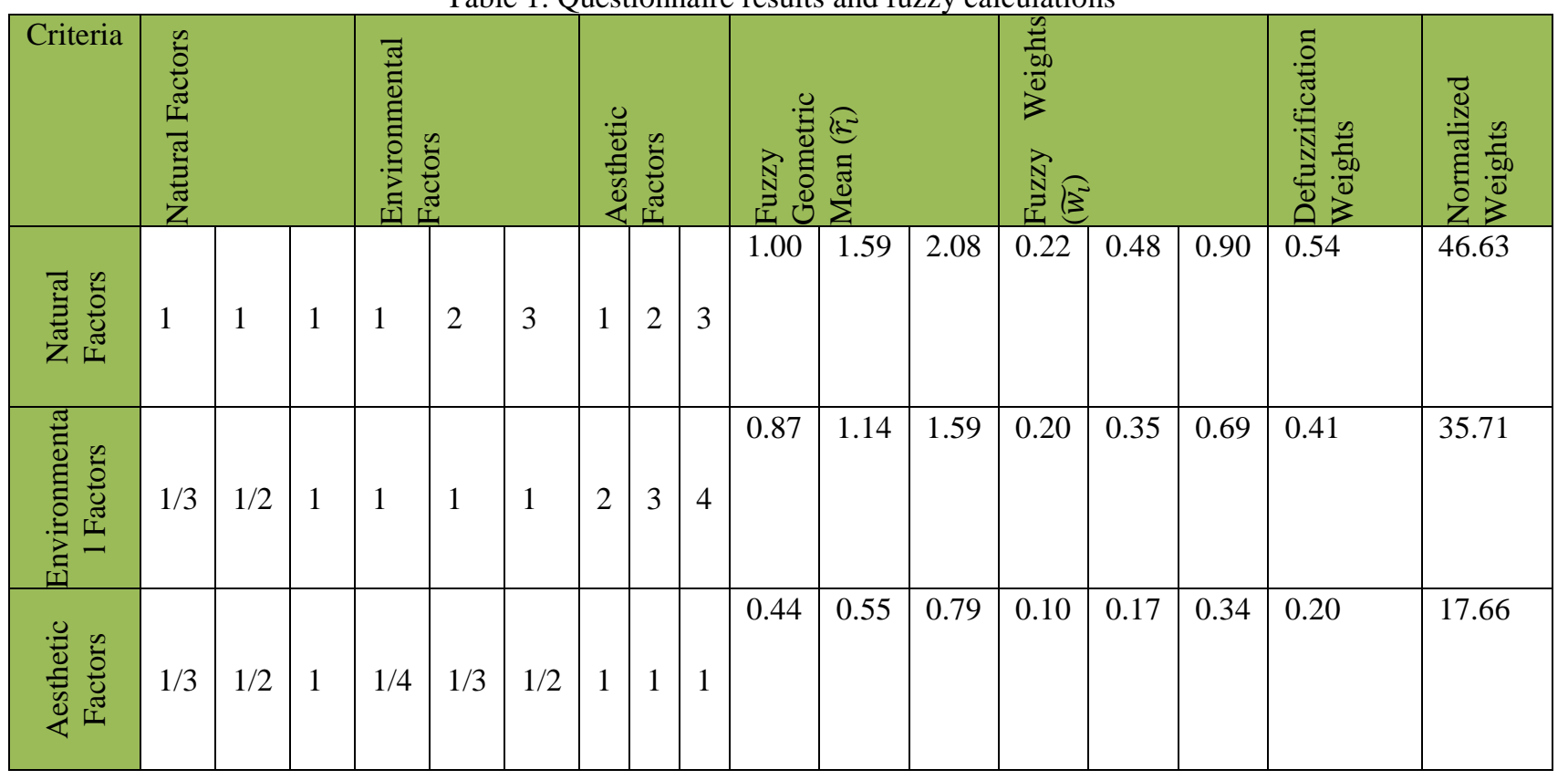

Since we got the reciprocal value of the fuzzy AHP, we can calculate the Fuzzy Geometric Mean $\left(\widetilde{r}_{l}\right)$, Fuzzy Weights $\left(\widetilde{w_{l}}\right)$, Defuzzification Weight $\left(w_{i}\right)$, and Normalized Weight of the criteria.

\subsection{Calculation of fuzzy AHP}

Fuzzy AHP needs to calculate Fuzzy Geometric Mean, Fuzzy Weights, Defuzzification Weights, and Normalized Weights. To calculate Fuzzy Geometric Mean Value ( $\left.\widetilde{r}_{l}\right)$, we used Eq. (1).

$$
\left(\widetilde{r_{l}}\right)=\widetilde{A_{1}} \otimes \widetilde{A_{2}} \otimes \widetilde{A_{\ldots}} \widetilde{\otimes A_{n}}
$$

where,

$$
\widetilde{A_{n}}=\text { sub-criteria of } n
$$

Then, we calculate the Fuzzy weight using Eq. (2).

$$
\left(\widetilde{w_{l}}\right)=\widetilde{r}_{l} \times\left(\widetilde{r_{1}} \times \widetilde{r_{2}} \times \ldots \times \widetilde{r_{n}}\right)^{-1}
$$

The resulting Fuzzy weights is then used for defuzzification weight calculation using Eq. (3).

$$
w_{i}=\left(\frac{l+m+u}{3}\right)
$$

To calculate the Normalized weight, each defuzzification weight of the criteria is divided by the sum of defuzzification weight of all criteria as shown in Eq. (4).

$$
W=\frac{w_{i}}{\sum w} \cdot 100
$$

The calculation result of the normalized weight of each criterion and sub criterion is shown in Table 2.

\subsection{Spatial analysis with arcmap}

The criteria we gathered are grouped into 3 categories; natural factors, environmental factors, and aesthetic factors. These are the explanations.

\subsubsection{Natural factors}

Morphology; mining activities and worker safety and security factors will be better if the mining location is located in lower slope. Based on this criterion, the mining location might be more secure. In this study, hills with steep slopes scored 1, moderate hill slope scored 2 and the slopes of the hills scored 3.

Lithology; The most important material in Sirtu mining is alluvial lithology, these materials can be excavated easier than other materials. The other material that is one of the easier materials to excavate are sediment. Thus, Alluvial lithology scored 3 in this study, sediment lithology scored 2 and other lithologies scored 1.

Hydrology; The activity of Sirtu Mining are greatly affected by how often rain occur on site, especially when excavation process is underway. In this study, sub-district with rainfall capacity of more than $15 \mathrm{~mm} /$ day are given score of 1 , while rainfall capacity between $15-20 \mathrm{~mm} /$ day scored 2 , and area with rainfall capacity less than $15 \mathrm{~mm} /$ day are given score of 3 . 
Table 2. Weighted index of fuzzy AHP

\begin{tabular}{|c|c|c|c|c|c|}
\hline Criteria & $\begin{array}{l}\text { Criteria } \\
\text { Weight }\end{array}$ & & Sub Criteria & $\begin{array}{c}\text { Sub Criteria } \\
\text { Weight }\end{array}$ & $\begin{array}{c}\text { Final } \\
\text { Weight }\end{array}$ \\
\hline \multirow{3}{*}{ Natural Factors } & \multirow{3}{*}{46.63} & $\mathrm{C} 1$ & Geomorphology & 7.59 & 3.54 \\
\hline & & $\mathrm{C} 2$ & Lithology & 77.72 & 36.24 \\
\hline & & C3 & Hidrology & 14.69 & 6.85 \\
\hline \multirow{5}{*}{ Environmental Factors } & \multirow{5}{*}{35.71} & $\mathrm{C} 4$ & Vegetation & 4.49 & 1.60 \\
\hline & & C5 & Wildlife & 5.81 & 2.08 \\
\hline & & C6 & Distance from Mainroad & 42.11 & 15.04 \\
\hline & & $\mathrm{C} 7$ & Distance from Settlement & 33.10 & 11.82 \\
\hline & & $\mathrm{C} 8$ & Population Density & 14.49 & 5.17 \\
\hline \multirow{2}{*}{ Aesthetic Factors } & \multirow{2}{*}{17.66} & C9 & Natural Features & 35.61 & 6.29 \\
\hline & & $\mathrm{C} 10$ & Touristic Places & 64.39 & 11.37 \\
\hline
\end{tabular}

\subsubsection{Environmental factors}

Vegetation; Mining activities needs to minimizes the damage to the surrounding vegetation. Area with low vegetation is better. In this study, location with $60 \%$ or more vegetation area got 1 for this criteria score, while location with $30-60 \%$ vegetation scored 2 . Area with vegetation area of $30 \%$ or below scored 3.

Wildlife; Mining activities should not disturb the habitat of any wild animals. Thus, minimal interruption of the animal habitat is better. In this study, location with more than $50 \%$ wildlife area got a scored 1, while location with $25-50 \%$ wildlife area scored 2. Area with wildlife area less than $25 \%$ scored 3.

Distance from the main road; Mining activities that is closer to the primary highway will lessen the transport expenses. Therefore, mining site that is closer to the highway will be better. Hence, this might have a bad impact on social and environmental factors. In this research, sub-district with main road access of more than $5 \mathrm{~km}$ are given a score of 1, while the sub-district of $2.5 \mathrm{~km}-5 \mathrm{~km}$ radius are scored 2 . Area with less than $2.5 \mathrm{~km}$ radius of the main road scored 3.

Distance from the settlement; The closer the settlement's mine site, the smaller the negative affect on the environment. In this study, the if a sub district have a settlement in $1 \mathrm{~km}$ radius from the mining location, the sub district will be scored 1 in this criteria, while if the settlement is in $1-2 \mathrm{~km}$ radius of the mining location, It will be given a score of 2 . Mining location in more than $2 \mathrm{~km}$ radius of settlement will be given a score of 3 .

Population density; the less population near the mining area is better since the smaller negative effect could happens to the people. Subdistrict with more than 1.5 million people per $\mathrm{km} 2$ scored 1 in this study, while sub-district scored 2 with 1-1.5 million people per $\mathrm{km} 2$. The district with less than one million people per $\mathrm{km} 2$ is given the score of 3 .

\subsubsection{Aesthetic factors}

Natural Features; Mining activities should not damage natural environments such as forests, mountains, waterfalls, landscapes, caves, and springs. Sub-district with 3 or more natural features is given a score of 1, while location with 2-3 natural features got score 2. Location with no natural features is scored 3.

Touristic Places; Mining activities should try to avoid touristic places since it can disturb the tourists. Location with more than 10 touristic places got a score of 1, while location with 5-10 touristic places got score 2. The highest score is the location with less than 5 or no touristic places.

Then based on GIS analysis, the Table 3 is obtained. 
Table 3. Decision matrix

\begin{tabular}{|c|c|c|c|c|c|c|c|c|c|c|c|}
\hline \multirow[b]{3}{*}{$\dot{z}$} & \multirow[b]{3}{*}{ 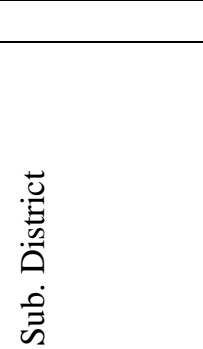 } & $\operatorname{Max}$ & Max & Min & Min & Min & Min & Max & Min & Min & Min \\
\hline & & $\mathrm{C} 1$ & $\mathrm{C} 2$ & C3 & $\mathrm{C} 4$ & C5 & C6 & C7 & C8 & C9 & $\mathrm{C} 10$ \\
\hline & & 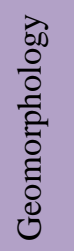 & 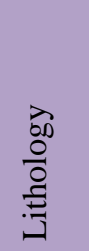 & 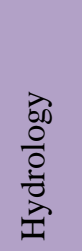 & 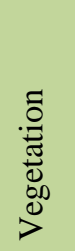 & $\frac{\stackrel{0}{0}}{\stackrel{0}{\frac{7}{3}}}$ & 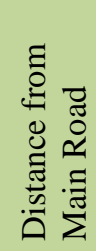 & 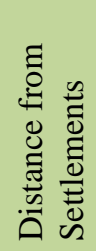 & 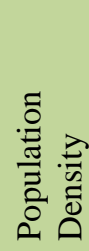 & 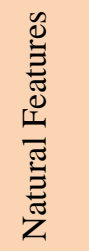 & 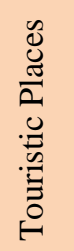 \\
\hline 1 & Banyakan & 2.58 & 2.39 & 1.00 & 3.00 & 3.00 & 2.17 & 2.24 & 1.00 & 1.00 & 1.00 \\
\hline 2 & Gampengrejo & 1.00 & 2.80 & 2.00 & 2.00 & 1.00 & 1.19 & 1.59 & 3.00 & 1.00 & 3.00 \\
\hline 3 & Grogol & 1.90 & 2.83 & 3.00 & 2.00 & 1.00 & 1.98 & 1.54 & 2.00 & 3.00 & 2.00 \\
\hline 4 & Kandangan & 1.00 & 1.41 & 2.00 & 2.00 & 1.00 & 2.88 & 1.69 & 2.00 & 2.00 & 3.00 \\
\hline 5 & Kandat & 1.00 & 2.24 & 3.00 & 2.00 & 1.00 & 1.44 & 1.44 & 2.00 & 1.00 & 1.00 \\
\hline 6 & Kepung & 2.27 & 1.48 & 1.00 & 2.00 & 2.00 & 2.95 & 1.82 & 1.00 & 2.00 & 3.00 \\
\hline 7 & Kras & 1.00 & 2.90 & 2.00 & 1.00 & 1.00 & 1.42 & 1.35 & 2.00 & 1.00 & 1.00 \\
\hline 8 & Kunjang & 1.00 & 2.88 & 3.00 & 1.00 & 1.00 & 2.91 & 1.24 & 1.00 & 1.00 & 1.00 \\
\hline 9 & Mojo & 2.69 & 2.76 & 3.00 & 3.00 & 2.00 & 2.61 & 2.49 & 1.00 & 3.00 & 1.00 \\
\hline 10 & Ngadiluwih & 1.00 & 2.79 & 2.00 & 1.00 & 1.00 & 1.05 & 1.12 & 3.00 & 1.00 & 2.00 \\
\hline 11 & Ngancar & 2.40 & 1.05 & 1.00 & 3.00 & 1.00 & 3.00 & 2.01 & 1.00 & 2.00 & 1.00 \\
\hline 12 & Papar & 1.00 & 3.00 & 3.00 & 1.00 & 1.00 & 1.43 & 1.20 & 2.00 & 1.00 & 1.00 \\
\hline 13 & Pare & 1.00 & 2.83 & 2.00 & 2.00 & 1.00 & 1.38 & 1.59 & 3.00 & 1.00 & 2.00 \\
\hline 14 & Plosoklaten & 1.85 & 1.48 & 1.00 & 2.00 & 1.00 & 2.93 & 1.74 & 1.00 & 2.00 & 1.00 \\
\hline 15 & Puncu & 2.24 & 1.21 & 1.00 & 2.00 & 3.00 & 2.91 & 1.75 & 1.00 & 2.00 & 1.00 \\
\hline 16 & Purwoasri & 1.00 & 3.00 & 3.00 & 2.00 & 1.00 & 1.91 & 1.56 & 3.00 & 1.00 & 1.00 \\
\hline 17 & Semen & 2.80 & 2.40 & 2.00 & 3.00 & 3.00 & 2.70 & 2.48 & 1.00 & 3.00 & 2.00 \\
\hline 18 & Tarokan & 1.98 & 3.00 & 2.00 & 2.00 & 1.00 & 1.55 & 1.51 & 2.00 & 3.00 & 1.00 \\
\hline 19 & Wates & 1.00 & 1.53 & 2.00 & 2.00 & 1.00 & 2.73 & 1.70 & 2.00 & 1.00 & 2.00 \\
\hline
\end{tabular}

Table 4. SAW rank results

\begin{tabular}{|c|c|c|c|c|c|c|c|c|c|c|c|c|c|}
\hline \multirow[b]{3}{*}{$\dot{i}$} & & Max & Max & Min & Min & Min & Min & Max & Min & Min & Min & & \\
\hline & & $\mathrm{C} 1$ & $\mathrm{C} 2$ & $\mathrm{C} 3$ & $\mathrm{C} 4$ & C5 & C6 & C7 & $\mathrm{C} 8$ & C9 & C10 & \multirow[b]{2}{*}{$U i$} & \multirow[b]{2}{*}{ 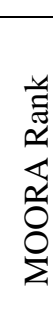 } \\
\hline & 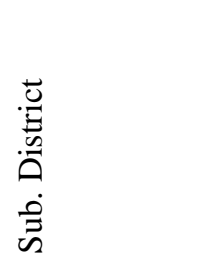 & $\begin{array}{l}\text { के } \\
0 \\
0 \\
\overline{0} \\
\overline{0} \\
0 \\
0 \\
0 \\
0\end{array}$ & 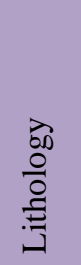 & 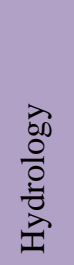 & 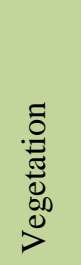 & 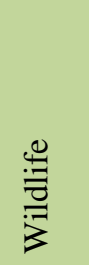 & 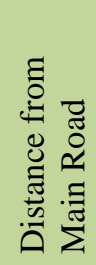 & 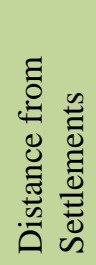 & 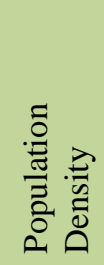 & 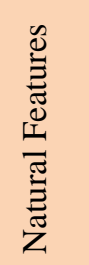 & 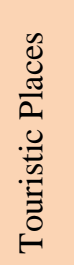 & & \\
\hline 1 & Banyakan & 0.86 & 0.80 & 1.00 & 0.33 & 0.33 & 0.46 & 1.12 & 1.00 & 1.00 & 1.00 & 0.83 & 1 \\
\hline 2 & Gampengrejo & 0.33 & 0.93 & 0.50 & 0.50 & 1.00 & 0.84 & 0.79 & 0.33 & 1.00 & 0.33 & 0.75 & 10 \\
\hline 3 & Grogol & 0.63 & 0.94 & 0.33 & 0.50 & 1.00 & 0.50 & 0.77 & 0.50 & 0.33 & 0.50 & 0.69 & 13 \\
\hline 4 & Kandangan & 0.33 & 0.47 & 0.50 & 0.50 & 1.00 & 0.35 & 0.84 & 0.50 & 0.50 & 0.33 & 0.49 & 19 \\
\hline 5 & Kandat & 0.33 & 0.75 & 0.33 & 0.50 & 1.00 & 0.70 & 0.72 & 0.50 & 1.00 & 1.00 & 0.73 & 11 \\
\hline 6 & Kepung & 0.76 & 0.49 & 1.00 & 0.50 & 0.50 & 0.34 & 0.91 & 1.00 & 0.50 & 0.33 & 0.57 & 17 \\
\hline 7 & Kras & 0.33 & 0.97 & 0.50 & 1.00 & 1.00 & 0.71 & 0.67 & 0.50 & 1.00 & 1.00 & 0.82 & 2 \\
\hline 8 & Kunjang & 0.33 & 0.96 & 0.33 & 1.00 & 1.00 & 0.34 & 0.62 & 1.00 & 1.00 & 1.00 & 0.77 & 7 \\
\hline 9 & Mojo & 0.90 & 0.92 & 0.33 & 0.33 & 0.50 & 0.38 & 1.25 & 1.00 & 0.33 & 1.00 & 0.80 & 4 \\
\hline 10 & Ngadiluwih & 0.33 & 0.93 & 0.50 & 1.00 & 1.00 & 0.95 & 0.56 & 0.33 & 1.00 & 0.50 & 0.77 & 8 \\
\hline 11 & Ngancar & 0.80 & 0.35 & 1.00 & 0.33 & 1.00 & 0.33 & 1.01 & 1.00 & 0.50 & 1.00 & 0.62 & 15 \\
\hline 12 & Papar & 0.33 & 1.00 & 0.33 & 1.00 & 1.00 & 0.70 & 0.60 & 0.50 & 1.00 & 1.00 & 0.81 & 3 \\
\hline 13 & Pare & 0.33 & 0.94 & 0.50 & 0.50 & 1.00 & 0.72 & 0.80 & 0.33 & 1.00 & 0.50 & 0.76 & 9 \\
\hline 14 & Plosoklaten & 0.62 & 0.49 & 1.00 & 0.50 & 1.00 & 0.34 & 0.87 & 1.00 & 0.50 & 1.00 & 0.65 & 14 \\
\hline 15 & Puncu & 0.75 & 0.40 & 1.00 & 0.50 & 0.33 & 0.34 & 0.88 & 1.00 & 0.50 & 1.00 & 0.61 & 16 \\
\hline 16 & Purwoasri & 0.33 & 1.00 & 0.33 & 0.50 & 1.00 & 0.52 & 0.78 & 0.33 & 1.00 & 1.00 & 0.79 & 6 \\
\hline 17 & Semen & 0.93 & 0.80 & 0.50 & 0.33 & 0.33 & 0.37 & 1.24 & 1.00 & 0.33 & 0.50 & 0.70 & 12 \\
\hline 18 & Tarokan & 0.66 & 1.00 & 0.50 & 0.50 & 1.00 & 0.64 & 0.75 & 0.50 & 0.33 & 1.00 & 0.80 & 5 \\
\hline 19 & Wates & 0.33 & 0.51 & 0.50 & 0.50 & 1.00 & 0.37 & 0.85 & 0.50 & 1.00 & 0.50 & 0.56 & 18 \\
\hline
\end{tabular}




\subsection{SAW ranking process}

At the stage of identification of potential zone sequences using SAW Method, the input data used is data on the Decision Matrix and the criteria weight that has been calculated from the Fuzzy AHP Method. To get the order of sub-districts with the most suitable potential based on the SAW Method, the sequence of calculations is as follows:

a) Normalization matrix, carried out in the following ways:

- For maximized criteria in $\mathrm{C} 1, \mathrm{C} 2$ and $\mathrm{C} 7$, we used Eq. (5).

$$
r_{i j}(x)=x_{i j} / \max \left\{x_{j}\right\}
$$

where the value of $x_{i j}$ is the alternative value $i$ in the criteria $j$ based on Table 3. While the value of max $\left\{x_{j}\right\}$ is the maximum value of in criteria $j$.

- For the minimized criteria for C3, C4, C4, C6, C8, C9 and C10, use Eq. (6).

$$
r_{i j}(x)=\min \left\{x_{j}\right\} / x_{i j}
$$

where the value of min $x_{i j}$ is the minimum value in the criteria $j$.

b) Determine the weight values of each alternative with Eq. (7).

$$
U_{i}(x)=\sum_{j=1}^{n} w_{j} r_{i j}(x)
$$

where $w_{j}$ is the weight of the criteria $j$ which has been calculated on the weighting of criteria using Fuzzy AHP.

Table 4 shows the results of SAW ranking process based on the above steps. Based on SAW, Banyakan sub district is the most ideal location since it is acquired rank 1. Followed by Kras sub district as the it is acquired rank 2. Thus, if some other obstacles happen and Banyakan cannot be used as a mining location, Kras would be the ideal choice based on SAW.

\subsection{MOORA ranking process}

MOORA can use the same decision matrix as shown in Table 3 for this case. The difference of this method is the ranking process of MOORA. The calculation process of MOORA method are as

\begin{tabular}{|c|c|c|c|c|c|c|c|c|c|c|c|c|c|}
\hline \multirow[b]{3}{*}{$\dot{z}$} & & Max & Max & Min & Min & Min & Min & Max & Min & Min & Min & \multirow[b]{3}{*}{$Q i$} & \multirow[b]{3}{*}{ 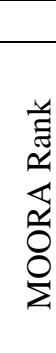 } \\
\hline & & $\mathrm{C} 1$ & $\mathrm{C} 2$ & $\mathrm{C} 3$ & $\mathrm{C} 4$ & C5 & C6 & C7 & C8 & C9 & $\mathrm{C} 10$ & & \\
\hline & 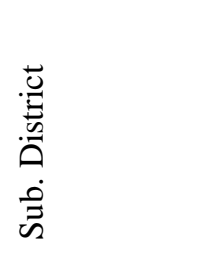 & $\begin{array}{l}\text { के } \\
\frac{0}{0} \\
\stackrel{0}{0} \\
\stackrel{0}{0} \\
0 \\
\vdots \\
0 \\
0\end{array}$ & 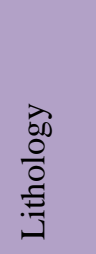 & 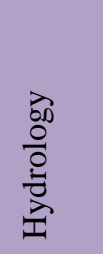 & 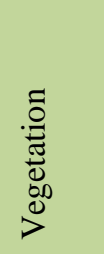 & 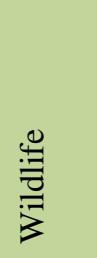 & 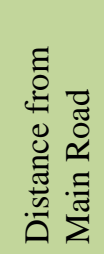 & 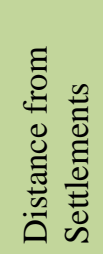 & 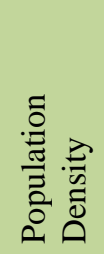 & 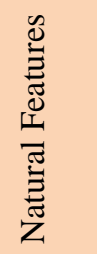 & 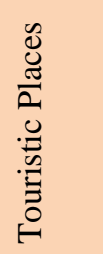 & & \\
\hline 1 & Banyakan & 0.012 & 0.082 & 0.007 & 0.005 & 0.009 & 0.033 & 0.035 & 0.006 & 0.008 & 0.015 & 0.046 & 2 \\
\hline 2 & Gampengrejo & 0.005 & 0.096 & 0.014 & 0.003 & 0.003 & 0.018 & 0.025 & 0.018 & 0.008 & 0.045 & 0.016 & 11 \\
\hline 3 & Grogol & 0.009 & 0.098 & 0.022 & 0.003 & 0.003 & 0.030 & 0.024 & 0.012 & 0.023 & 0.030 & 0.007 & 12 \\
\hline 4 & Kandangan & 0.005 & 0.049 & 0.014 & 0.003 & 0.003 & 0.044 & 0.026 & 0.012 & 0.015 & 0.045 & -0.057 & 19 \\
\hline 5 & Kandat & 0.005 & 0.077 & 0.022 & 0.003 & 0.003 & 0.022 & 0.023 & 0.012 & 0.008 & 0.015 & 0.020 & 10 \\
\hline 6 & Kepung & 0.010 & 0.051 & 0.007 & 0.003 & 0.006 & 0.045 & 0.028 & 0.006 & 0.015 & 0.045 & -0.038 & 18 \\
\hline 7 & Kras & 0.005 & 0.100 & 0.014 & 0.002 & 0.003 & 0.021 & 0.021 & 0.012 & 0.008 & 0.015 & 0.050 & 1 \\
\hline 8 & Kunjang & 0.005 & 0.099 & 0.022 & 0.002 & 0.003 & 0.044 & 0.019 & 0.006 & 0.008 & 0.015 & 0.024 & 9 \\
\hline 9 & Mojo & 0.012 & 0.095 & 0.022 & 0.005 & 0.006 & 0.040 & 0.039 & 0.006 & 0.023 & 0.015 & 0.030 & 6 \\
\hline 10 & Ngadiluwih & 0.005 & 0.096 & 0.014 & 0.002 & 0.003 & 0.016 & 0.018 & 0.018 & 0.008 & 0.030 & 0.027 & 8 \\
\hline 11 & Ngancar & 0.011 & 0.036 & 0.007 & 0.005 & 0.003 & 0.045 & 0.032 & 0.006 & 0.015 & 0.015 & -0.019 & 15 \\
\hline 12 & Papar & 0.005 & 0.103 & 0.022 & 0.002 & 0.003 & 0.022 & 0.019 & 0.012 & 0.008 & 0.015 & 0.044 & 3 \\
\hline 13 & Pare & 0.005 & 0.097 & 0.014 & 0.003 & 0.003 & 0.021 & 0.025 & 0.018 & 0.008 & 0.030 & 0.029 & 7 \\
\hline 14 & Plosoklaten & 0.009 & 0.051 & 0.007 & 0.003 & 0.003 & 0.044 & 0.027 & 0.006 & 0.015 & 0.015 & -0.008 & 14 \\
\hline 15 & Puncu & 0.010 & 0.042 & 0.007 & 0.003 & 0.009 & 0.044 & 0.028 & 0.006 & 0.015 & 0.015 & -0.021 & 16 \\
\hline 16 & Purwoasri & 0.005 & 0.103 & 0.022 & 0.003 & 0.003 & 0.029 & 0.024 & 0.018 & 0.008 & 0.015 & 0.034 & 5 \\
\hline 17 & Semen & 0.013 & 0.083 & 0.014 & 0.005 & 0.009 & 0.041 & 0.039 & 0.006 & 0.023 & 0.030 & 0.006 & 13 \\
\hline 18 & Tarokan & 0.009 & 0.103 & 0.014 & 0.003 & 0.003 & 0.024 & 0.024 & 0.012 & 0.023 & 0.015 & 0.041 & 4 \\
\hline 19 & Wates & 0.005 & 0.053 & 0.014 & 0.003 & 0.003 & 0.041 & 0.027 & 0.012 & 0.008 & 0.030 & -0.028 & 17 \\
\hline
\end{tabular}
follows:

Table 5. MOORA method optimization matrix 
Table 6. COPRAS method optimization matrix

\begin{tabular}{|c|c|c|c|c|c|c|c|c|c|c|c|c|c|}
\hline \multirow[b]{3}{*}{$\dot{\mathbf{z}}$} & & Max & Max & Min & Min & Min & Min & Max & Min & Min & Min & \multirow[b]{3}{*}{$Q i$} & \multirow[b]{3}{*}{ 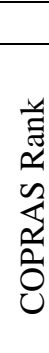 } \\
\hline & & $\mathrm{C} 1$ & $\mathrm{C} 2$ & C3 & $\mathrm{C} 4$ & C5 & C6 & C7 & C8 & C9 & $\mathrm{C} 10$ & & \\
\hline & 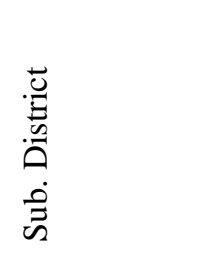 & 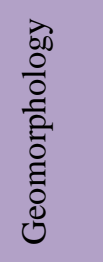 & 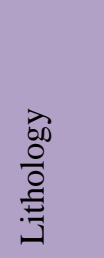 & 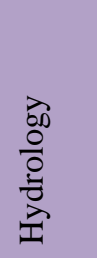 & 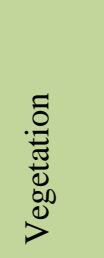 & $\frac{\mathscr{0}}{\stackrel{0}{7}}$ & 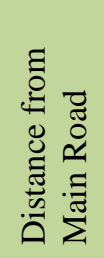 & 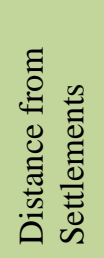 & 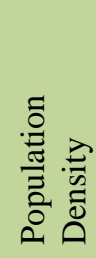 & 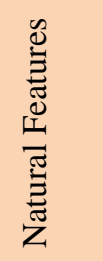 & 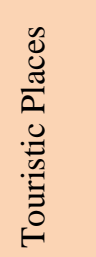 & & \\
\hline 1 & Banyakan & 0.003 & 0.020 & 0.002 & 0.001 & 0.002 & 0.008 & 0.008 & 0.002 & 0.002 & 0.004 & 0.062 & 2 \\
\hline 2 & Gampengrejo & 0.001 & 0.023 & 0.004 & 0.001 & 0.001 & 0.004 & 0.006 & 0.005 & 0.002 & 0.011 & 0.053 & 11 \\
\hline 3 & Grogol & 0.002 & 0.023 & 0.005 & 0.001 & 0.001 & 0.007 & 0.006 & 0.003 & 0.006 & 0.008 & 0.052 & 13 \\
\hline 4 & Kandangan & 0.001 & 0.012 & 0.004 & 0.001 & 0.001 & 0.011 & 0.006 & 0.003 & 0.004 & 0.011 & 0.038 & 19 \\
\hline 5 & Kandat & 0.001 & 0.018 & 0.005 & 0.001 & 0.001 & 0.005 & 0.005 & 0.003 & 0.002 & 0.004 & 0.055 & 10 \\
\hline 6 & Kepung & 0.003 & 0.012 & 0.002 & 0.001 & 0.002 & 0.011 & 0.007 & 0.002 & 0.004 & 0.011 & 0.041 & 18 \\
\hline 7 & Kras & 0.001 & 0.024 & 0.004 & 0.000 & 0.001 & 0.005 & 0.005 & 0.003 & 0.002 & 0.004 & 0.064 & 1 \\
\hline 8 & Kunjang & 0.001 & 0.024 & 0.005 & 0.000 & 0.001 & 0.011 & 0.005 & 0.002 & 0.002 & 0.004 & 0.055 & 9 \\
\hline 9 & Mojo & 0.003 & 0.023 & 0.005 & 0.001 & 0.002 & 0.010 & 0.009 & 0.002 & 0.006 & 0.004 & 0.057 & 6 \\
\hline 10 & Ngadiluwih & 0.001 & 0.023 & 0.004 & 0.000 & 0.001 & 0.004 & 0.004 & 0.005 & 0.002 & 0.008 & 0.056 & 8 \\
\hline 11 & Ngancar & 0.003 & 0.009 & 0.002 & 0.001 & 0.001 & 0.011 & 0.007 & 0.002 & 0.004 & 0.004 & 0.045 & 15 \\
\hline 12 & Papar & 0.001 & 0.025 & 0.005 & 0.000 & 0.001 & 0.005 & 0.004 & 0.003 & 0.002 & 0.004 & 0.061 & 3 \\
\hline 13 & Pare & 0.001 & 0.023 & 0.004 & 0.001 & 0.001 & 0.005 & 0.006 & 0.005 & 0.002 & 0.008 & 0.056 & 7 \\
\hline 14 & Plosoklaten & 0.002 & 0.012 & 0.002 & 0.001 & 0.001 & 0.011 & 0.006 & 0.002 & 0.004 & 0.004 & 0.048 & 14 \\
\hline 15 & Puncu & 0.003 & 0.010 & 0.002 & 0.001 & 0.002 & 0.011 & 0.006 & 0.002 & 0.004 & 0.004 & 0.044 & 16 \\
\hline 16 & Purwoasri & 0.001 & 0.025 & 0.005 & 0.001 & 0.001 & 0.007 & 0.006 & 0.005 & 0.002 & 0.004 & 0.058 & 5 \\
\hline 17 & Semen & 0.003 & 0.020 & 0.004 & 0.001 & 0.002 & 0.010 & 0.009 & 0.002 & 0.006 & 0.008 & 0.052 & 12 \\
\hline 18 & Tarokan & 0.002 & 0.025 & 0.004 & 0.001 & 0.001 & 0.006 & 0.006 & 0.003 & 0.006 & 0.004 & 0.059 & 4 \\
\hline 19 & Wates & 0.001 & 0.013 & 0.004 & 0.001 & 0.001 & 0.010 & 0.006 & 0.003 & 0.002 & 0.008 & 0.043 & 17 \\
\hline
\end{tabular}

a) Normalization Matrix, which can be stated in Eq. (8).

$$
X_{i j}=\frac{x_{i j}}{\sqrt{\left[\sum_{j=1}^{m} x_{i j}^{2}\right]}}
$$

where $x_{i j}$ is the value based on decision matrix of row $i$.and column $j$. Therefore, based on Eq. (8), Normalization Matrix produced.

b) To calculate Optimization Values $\left(Q_{i}\right)$, we need to split the criteria into maximized and minimized criteria. Then, subtract the result of the maximized value and the minimized value as shown in Eq. (9).

$$
Q_{i}=\sum_{j=1}^{g} w_{j} x^{*}{ }_{i j}-\sum_{j=g+1}^{n} w_{j} x^{*}{ }_{i j}
$$

$\sum_{j=1}^{g} w_{j} x^{*}{ }_{i j}$ is a component of maximized criteria, namely criteria $\mathrm{C} 1, \mathrm{C} 2$ and $\mathrm{C} 7$, while $\sum_{j=g+1}^{n} w_{j} x^{*}{ }_{i j}$ is a minimized component of criteria $\mathrm{C} 3, \mathrm{C} 4, \mathrm{C} 4, \mathrm{C} 6$, $\mathrm{C} 8, \mathrm{C} 9$ and $\mathrm{C} 10$.

Table 5 shows the result of MOORA method. Different to the result of SAW method, Kras sub district is the most suitable location based on MOORA. Thus, the result of the most ideal location is shifting. The difference of optimization method results in different ranking result.

\subsection{COPRAS ranking process}

COPRAS uses the same decision matrix shown on Table 3 for its identification phase. To determine the rank of each criteria, the provided decision matrix is used to create normalization matrix.

a) To create normalization matrix using COPRAS, we used Eq. (10).

$$
r_{i j}=\frac{x_{i j}}{\sum_{i=1}^{N} x_{i j}}
$$

b) To calculate the optimization values, we do separate calculation for criteria which needs to be maximized and criteria which needs to be minimized. Eq. (11) shows calculation for maximized criteria, while Eq. (12) shows calculation for minimized criteria.

$$
\begin{aligned}
& S_{+i}=\sum_{j \Omega \max } w_{j} r_{i j} \\
& S_{-i}=\sum_{j \Omega \min } w_{j} r_{i j}
\end{aligned}
$$

where, 
$j \Omega \max =$ criteria that needs to be maximized

$j \Omega \min =$ criteria that needs to be minimized

c) Based on the optimization values, we can calculate the rank produced by COPRAS method $\left(Q_{i}\right)$ using Eq. (13).

$$
Q_{i}=S_{+i}+\left[\frac{\sum_{i=1}^{m} S_{-i}}{S_{-i} \sum_{i=1}^{m}\left(\frac{1}{S_{-i}}\right)}\right]
$$

Based on Eq. (13), $S_{+i}$ is the value of the maximized optimization value and $S_{-i}$ as the minimized criteria optimization value. Table 6 shows the ranking result of COPRAS.

As shown in Table 6, the result of COPRAS method is more similar to MOORA method compared to SAW. This is due to the normalization and optimization method that is similar in both methods.

\subsection{Comparison of SAW, MOORA and COPRAS ranking}

To calculate the accuracy of the method, this study compares the results of the ranking of the aggregation process with the ranking results of each method. The accuracy of this method is then calculated based on the point of each method compared to the total point of all scenarios.

To determine the best alternative sequence, rankings were collected from the SAW, MOORA and COPRAS methods. For 19 sub-districts as the alternative, each best alternative gets 19 points, 19-1 if the alternative is ranked second, and so on for each scenario. The alternative with the highest point is the best overall result. On the Table 7, the total points for each alternative sub-district is shown. The rank of each sub-district based on the aggregation method is shown in Table 8.

Based on Table 8, the result of 3 MCDM method shows that Kras sub district is the most suitable location for mining. Therefore, MOORA and COPRAS got 1 point on the accuracy score while SAW got 0 point.

Table 9 shows the accuracy point each method get by comparing the result on Table 8 and each method result.

Based on Table 9, the result of all the method is compared to the aggregate results in each scenario. The SAW method gets a total of 8/19 points, while the MOORA 17/19 Method and the highest total points are obtained by the COPRAS Method with 19/19 accuracy.
Table 7. SAW, MOORA and COPRAS final rank

\begin{tabular}{|c|c|c|c|c|}
\hline \multirow{2}{*}{$\begin{array}{c}\operatorname{Ran} \\
\mathrm{k}\end{array}$} & \multirow{2}{*}{$\begin{array}{c}\text { Scor } \\
\mathrm{e}\end{array}$} & \multicolumn{3}{|c|}{ Methods } \\
\hline & & SAW & MOORA & COPRAS \\
\hline 1 & 19 & Banyakan & Kras & Kras \\
\hline 2 & 18 & Kras & Banyakan & Banyakan \\
\hline 3 & 17 & Papar & Papar & Papar \\
\hline 4 & 16 & Mojo & Tarokan & Tarokan \\
\hline 5 & 15 & Tarokan & Purwosari & Purwosari \\
\hline 6 & 14 & Purwosari & Mojo & Mojo \\
\hline 7 & 13 & Kunjang & Pare & Pare \\
\hline 8 & 12 & $\begin{array}{c}\text { Ngadiluwi } \\
\mathrm{h}\end{array}$ & $\begin{array}{c}\text { Ngadiluwi } \\
\mathrm{h}\end{array}$ & $\begin{array}{c}\text { Ngadiluwi } \\
h\end{array}$ \\
\hline 9 & 11 & Pare & Kunjang & Kunjang \\
\hline 10 & 10 & $\begin{array}{c}\text { Gampengre } \\
\text { jo }\end{array}$ & Kandat & Kandat \\
\hline 11 & 9 & Kandat & $\begin{array}{c}\text { Gampengre } \\
\text { jo }\end{array}$ & $\begin{array}{l}\text { Gampengre } \\
\text { jo }\end{array}$ \\
\hline 12 & 8 & Semen & Grogol & Semen \\
\hline 13 & 7 & Grogol & Semen & Grogol \\
\hline 14 & 6 & Plosoklaten & Plosoklaten & Plosoklaten \\
\hline 15 & 5 & Ngancar & Ngancar & Ngancar \\
\hline 16 & 4 & Puncu & Puncu & Puncu \\
\hline 17 & 3 & Kepung & Wates & Wates \\
\hline 18 & 2 & Wates & Kepung & Kepung \\
\hline 19 & 1 & Kandangan & Kandangan & Kandangan \\
\hline
\end{tabular}

Table 8. Calculation of the aggregation method

\begin{tabular}{|c|c|c|}
\hline Sub District & Score & Total Score \\
\hline Banyakan & $19+18+18$ & 55 \\
\hline Gampengrejo & $10+9+9$ & 28 \\
\hline Grogol & $7+8+7$ & 19 \\
\hline Kandangan & $1+1+1$ & 3 \\
\hline Kandat & $9+10+10$ & 29 \\
\hline Kepung & $3+2+2$ & 7 \\
\hline Kras & $18+19+19$ & 56 \\
\hline Kunjang & $13+11+11$ & 35 \\
\hline Mojo & $16+14+14$ & 44 \\
\hline Ngadiluwih & $12+12+12$ & 36 \\
\hline Ngancar & $5+5+5$ & 15 \\
\hline Papar & $17+17+17$ & 51 \\
\hline Pare & $11+13+13$ & 37 \\
\hline Plosoklaten & $6+6+6$ & 18 \\
\hline Puncu & $4+4+4$ & 12 \\
\hline Purwoasri & $14+15+15$ & 44 \\
\hline Semen & $8+7+8$ & 26 \\
\hline Tarokan & $15+16+16$ & 47 \\
\hline Wates & $2+3+3$ & 8 \\
\hline
\end{tabular}

\section{Conclusion}

To identify the sequence of potential zones of the Natural Sandy Gravel (Sirtu) mining, 3 main criteria were used. Based on the calculation of the Fuzzy AHP Method, the weighting criteria are namely: natural factors consist of geomorphology (3.54\%), lithology (36.2\%), hydrology (6.85\%), vegetation 
Table 9. Comparison of results of ranking of each method with aggregation results

\begin{tabular}{|c|c|c|c|c|c|c|c|}
\hline \multirow{2}{*}{ Rank } & \multirow{2}{*}{ Aggregation Results } & \multicolumn{5}{|c|}{ Methods } & \multicolumn{3}{c|}{ Aggregation Score } \\
\cline { 3 - 7 } & & SAW & MOORA & COPRAS & SAW & MOORA & COPRAS \\
\hline 1 & Kras & Banyakan & Kras & Kras & 0 & 1 & 1 \\
\hline 2 & Banyakan & Kras & Banyakan & Banyakan & 0 & 1 & 1 \\
\hline 3 & Papar & Papar & Papar & Papar & 1 & 1 & 1 \\
\hline 4 & Tarokan & Mojo & Tarokan & Tarokan & 0 & 1 & 1 \\
\hline 5 & Purwosari & Tarokan & Purwosari & Purwosari & 0 & 1 & 1 \\
\hline 6 & Mojo & Purwosari & Mojo & Mojo & 0 & 1 & 1 \\
\hline 7 & Pare & Kunjang & Pare & Pare & 0 & 1 & 1 \\
\hline 8 & Ngadiluwih & Ngadiluwih & Ngadiluwih & Ngadiluwih & 1 & 1 & 1 \\
\hline 9 & Kunjang & Pare & Kunjang & Kunjang & 0 & 1 & 1 \\
\hline 10 & Kandat & Gampengrejo & Kandat & Kandat & 0 & 1 & 1 \\
\hline 11 & Gampengrejo & Kandat & Gampengrejo & Gampengrejo & 0 & 1 & 1 \\
\hline 12 & Semen & Semen & Grogol & Semen & 1 & 0 & 1 \\
\hline 13 & Grogol & Grogol & Semen & Grogol & 1 & 0 & 1 \\
\hline 14 & Plosoklaten & Plosoklaten & Plosoklaten & Plosoklaten & 1 & 1 & 1 \\
\hline 15 & Ngancar & Ngancar & Ngancar & Ngancar & 1 & 1 & 1 \\
\hline 16 & Puncu & Puncu & Puncu & Puncu & 1 & 1 & 1 \\
\hline 17 & Wates & Kepung & Wates & Wates & 0 & 1 & 1 \\
\hline 18 & Kepung & Wates & Kepung & Kepung & 0 & 1 & 1 \\
\hline 19 & Kandangan & Kandangan & Kandangan & Kandangan & 1 & 1 & 1 \\
\hline & & & & $8 / 19$ & $17 / 19$ & $19 / 19$ \\
\hline
\end{tabular}

(1.6\%) and the wildlife (2.08\%). Second, environmental factors which contains distance from the main road $(15 \%)$, distance from the settlement $(11.8 \%)$ and population density $(5.17 \%)$. Third, aesthetic factors consist of natural features (6.29\%) and touristic places (11.4\%). The criteria for Fuzzy AHP and Decision Matrix are used to identify potential zone sequences based on the SAW, MOORA and COPRAS methods. To determine the most appropriate method, the Aggregation Method was used. COPRAS got 19/19 in aggregation

\section{Conflicts of Interest}

The authors declare no conflict of interest.

\section{Author Contributions}

Conceptualization, Adiba Sabilla Ajrina, Riyanarto Sarno and Aziz Fajar; methodology, Adiba Sabilla Ajrina; software, Adiba Sabilla Ajrina; validation, Riyanarto Sarno and Hari Ginardi; formal analysis, Aziz Fajar; resources, Riyanarto Sarno and Hari Ginardi; writing - original draft preparation, Adiba Sabilla Ajrina; writing-review and editing, Aziz Fajar and Riyanarto Sarno; visualization, Adiba Sabilla Ajrina; supervision, Riayanrto Sarno and Hari Ginardi.

\section{Acknowledgments}

This research was funded by the Indonesian Ministry of Education and Culture, and the
Indonesian Ministry of Research and Technology/National Agency for Research and Innovation, under PTUPT Program and PPKI Program Managed by Institut Teknologi Sepuluh Nopember (ITS), and LPDP under RISPRO Invitation program.

\section{References}

[1] A. Fajar and R. Sarno, "Optimization of time and cost of multi organization business processes in a port container terminal", International Journal of Intelligent Engineering and Systems, Vol. 12, No. 6, pp. 259-271, 2019.

[2] A. Cahyapratama, "Application of Analytic Hierarchy Process ( AHP ) and Simple Additive Weighting ( SAW ) Methods In Singer Selection Process", No. Mcdm, pp. 235-240, 2018.

[3] D. Y. H. Tanjung and R. Adawiyah, "Optimizing Selection of Decision Support System with Fuzzy Simple Additive Weighting", In: Proc. of 2018 6th Int. Conf. Cyber IT Serv. Manag. CITSM 2018, No. Citsm, pp. 1-4, 2019.

[4] H. Causa and W. K. M. Brauers, "Location of a seaport by MOORA optimization", In: Proc. of 2014 Int. Conf. Adv. Logist. Transp. ICALT 2014, pp. 275-280, 2014.

[5] A. V. Mangalan, S. Kuriakose, H. Mohamed, and A. Ray, "Optimal location of warehouse using weighted MOORA approach", In: Proc. of Int. Conf. Electr. Electron. Optim. Tech. ICEEOT 2016, No. 2, pp. 662-665, 2016. 
[6] P. Karande and S. Chakraborty, "Application of multi-objective optimization on the basis of ratio analysis ( MOORA ) method for materials selection", J. Mater., Vol. 37, pp. 317-324, 2012.

[7] G. Vijay. S, "Application of MOORA method for parametric optimization of milling process", Int. J. Appl. Eng. Res., Vol. 1, No. 4, pp. 743758, 2011.

[8] J. Achebo and W. E. Odinikuku, "Optimization of Gas Metal Arc Welding Process Parameters Using Standard Deviation ( SDV ) and MultiObjective Optimization on the Basis of Ratio Analysis (MOORA)", J. Miner. Mater. Charact. Eng., No. July, pp. 298-308, 2015.

[9] A. Kaklauskas, E. K. Zavadskas, and S. Raslanas, "Multivariant design and multiple criteria analysis of building refurbishments", Energy Build., Vol. 37, No. 4, pp. 361-372, 2005.

[10] A. Kaklauskas, E. K. Zavadskas, S. Raslanas, R. Ginevicius, A. Komka, and P. Malinauskas, "Selection of low-e windows in retrofit of public buildings by applying multiple criteria method COPRAS: A Lithuanian case", Energy Build., Vol. 38, No. 5, pp. 454-462, 2006.

[11] P. Pitchipoo, D. S. Vincent, and N. S. Rajakarunakaran, "COPRAS Decision Model to Optimize Blind Spot in Heavy Vehicles: A Comparative Perspective", Procedia Eng., Vol. 97, pp. 1049-1059, 2014.

[12] S. H. Mousavi-nasab and A. Sotoudeh-anvari, "A comprehensive MCDM-based approach using TOPSIS, COPRAS and DEA as an auxiliary tool for material selection problems", Mater. Des., Vol. 121, pp. 237-253, 2017.

[13] J. H. Kim, J. H. Han, Y. H. Kim, S. H. Choi, and E. S. Kim, "Preference-based solution selection algorithm for evolutionary multiobjective optimization", IEEE Trans. Evol. Comput., Vol. 16, No. 1, pp. 20-34, 2012.

[14] D. Stanujkic, B. Đorđević, and M. Đorđević, "Comparative Analysis of Some Prominent MCDM Methods: A Case of Ranking Serbian Banks", Serbian J. Manag., Vol. 8, No. 2, pp. 213-241, 2013.

[15] H. Li, W. Wang, L. Fan, Q. Li, and X. Chen, "A novel hybrid MCDM model for machine tool selection using fuzzy DEMATEL, entropy weighting and later defuzzification VIKOR", Appl. Soft Comput. J., Vol. 91, p. 106207, 2020.

[16] Ž. Stević, D. Pamučar, A. Puška, and P. Chatterjee, "Sustainable supplier selection in healthcare industries using a new MCDM method: Measurement of alternatives and ranking according to Compromise solution
(MARCOS)", Comput. Ind. Eng., Vol. 140, p. 106231, 2020.

[17] W. K. K. Hsu, S. J. Lian, and S. H. S. Huang, "An assessment model based on a hybrid MCDM approach for the port choice of liner carriers", Res. Transp. Bus. Manag., No. November, p. 100426, 2020.

[18] S. Barak and T. Mokfi, "Evaluation and selection of clustering methods using a hybrid group MCDM", Expert Syst. Appl., Vol. 138, 2019.

[19] A. Sabilla Ajrina, R. Sarno, and R. V. Hari Ginardi, "Comparison of AHP and BWM Methods Based on Geographic Information System for Determining Potential Zone of Pasir Batu Mining", In: Proc. of 2018 Int. Semin. Appl. Technol. Inf. Commun. Creat. Technol. Hum. Life, iSemantic 2018, pp. 453-457, 2018.

[20] K. A. Wiguna, R. Sarno, and N. F. Ariyani, "Optimization Solar Farm Site Selection Using Multi- Criteria Decision Making Fuzzy AHP and PROMETHEE: Case Study in Bali”, pp. 237-243, 2016.

[21] H. Lee and C. Chang, "Comparative analysis of MCDM methods for ranking renewable energy sources in Taiwan", Renew. Sustain. Energy Rev., Vol. 92, No. May, pp. 883-896, 2018.

[22] D. Y. Chang, "Applications of the extent analysis method on fuzzy AHP", Eur. J. Oper. Res., Vol. 95, No. 3, pp. 649-655, 1996. 